\title{
31. SULFIDE RELATIONS IN HOLE 418A FLOWS AND SULFUR CONTENTS OF GLASSES
}

\author{
E.A. Mathez, Department of Geological Sciences, University of Washington, Seattle, Washington
}

\section{INTRODUCTION}

Basalts that erupt on the ocean floor have $\mathrm{S}$ contents typically in the range 800 to $1500 \mathrm{ppm}$. This knowledge comes mainly from microprobe investigation of basaltic glasses (Moore and Fabbi, 1971; Mathez, 1976; Czamanske and Moore, 1977); such investigations also demonstrate that mafic melts are usually sulfide-saturated upon eruption. Although a reasonably clear picture of the behavior of $\mathrm{S}$ in basalts at near-liquidus temperatures emerges from these studies, no such picture arises from the wide and irregular variation exhibited by whole-rock $\mathrm{S}$ contents of crystalline basalts. This is not surprising since sulfides may be easily recrystallized and redistributed by hydrothermal activity. It is appropriate, therefore, to examine the behavior of sulfides as lavas crystallize and in deuteric environments if later redistribution processes are to be understood.

The thick coarse-grained flows penetrated near the bottom of Hole $418 \mathrm{~A}$ record gradation from magmatic to hydrothermal sulfide deposition. Thus, they offer an opportunity to study the textural and mineralogical details of sulfide evolution and serve as the focus of this work. Microprobe analyses of glasses, including determinations of their S contents, are also presented.

\section{GLASS COMPOSITIONS}

\section{Analytical Procedure}

Glasses were analyzed with an ARL EMX-SM electron microprobe at $15 \mathrm{kv}$ acceleration potential, with a $20-\mu \mathrm{m}$ beam, and at sample currents in the range 40 to 60 namps on anorthite, depending on the elements being analyzed. Natural and synthetic mineral standards and the EMPADR VII matrix correction program were used. Each analysis (Table 1) represents an average of 10 to 20 randomly chosen spots. All glasses were found to be homogeneous within counting statistics.

For S, the analytical procedure was the same as that used in a previous study (Mathez, 1976). In view of the slight discrepancy between the $\mathrm{Fe}-\mathrm{S}$ data of that study and those of Czamanske and Moore (1977), the analytical procedures for $\mathrm{S}$ and $\mathrm{Fe}$ analysis are reviewed below.

Figure 1 compares $\mathrm{S}$ concentrations in basalt glasses (non-DSDP) determined by microprobe with values determined by Delaney (1977) using the LECO method. The probe data used sulfide standards, and off-peak backgrounds (above and below) were measured on glasses representing an approprimate range of mean atomic number. The data were checked with multiple sulfide standards, two different matrix correction procedures (EMPADR VII and EMX2A), and on-peak background determinations on $\mathrm{S}$-free glasses. Conditions and counting times were chosen such that the average error due to counting statistics alone is $\pm 30 \mathrm{ppm}$ ( $2 \sigma$ value). LECO analyses are of crushed glasses hand-picked for high purity. The differences in the multiple LECO analyses available for two of the samples (Figure 1) suggest that complete purity was not always achieved; however, it is evident that the two methods are in good agreement.

The glass analyses of Table 1 utilize as an Fe standard either synthetic basalt glass or natural hypersthene, whereas Mathez's (1976) data were referred to various Fe-rich silicate standards (almandine, fayalite, hedenbergite). The use of these mineral standards yields Fe concentrations 2 to 3 relative per cent lower than $\mathrm{Fe}$ concentrations derived from the glass or hypersthene standards because of the large generation correction between Fe-rich mineral and basaltic glass pairs. The data of Figure 2, including those which have been reported previously, are referred to the glass or hypersthene standards; thus, the linear regression of Figure 2 is displaced to slightly higher $\mathrm{Fe}$ values compared to that of Mathez (1976). This accounts for most, but not all, of the above-mentioned discrepancy.

\section{Sulfur Contents of Glasses}

The $\mathrm{S}$ contents of glasses are summarized on Figure 2 and listed in Table 1. Figure 2 demonstrates that the glasses are entirely typical in terms of their S contents and that they were all at or near sulfide saturation upon quenching. The basis for this statement and the implications of the Fe-S relationship are discussed elsewhere (Mathez, 1976; Czamanske and Moore, 1977). However, for the sake of the discussion that follows, it should be noted that Figure 2 can be used to predict that separation of large quantities of sulfide-oxide liquid will not occur during initial stages of silicate liquid crystallization because increasing the $\mathrm{Fe}$ content of a residual liquid simply increases its sulfide saturation limit.

\section{HOLE 418A FLOWS}

Two flows from Hole 418A have been studied in detail. They are Sub-units 14B (Sections 418A-77-1 to 418A-79-7) and $14 \mathrm{C}$ (Sections 418A-80-1 to 418A-86-1), with apparent thicknesses of 27.9 and 38.3 meters, respectively. The inference that these sub-units are flows is based mainly on the presence of well-developed brecciated zones of quenched basalt at the top of each. Sub-unit 14B additionally contains thin (generally $<20 \mathrm{~cm}$ wide) dike-like structures with $\sim 2$-mm glass selvages. The composition of one such glass is presented in Table 1.

Shipboard analyses of samples from Sub-units 14B and $14 \mathrm{C}$ yield average $\mathrm{Fe}$ contents of 7.5 and $7.6 \mathrm{wt}$. per cent, respectively. From Figure 2, this corresponds to an initial S content of these lavas of $\sim 1150 \mathrm{ppm}$. 
TABLE 1

Microprobe Analyses of Glasses from Holes 417D, 418A, and 418B

\begin{tabular}{|c|c|c|c|c|c|c|c|c|}
\hline & $\begin{array}{l}\text { USNM }^{a} \\
113716\end{array}$ & $\begin{array}{l}\text { 417D-54-4, } \\
9-14 \mathrm{~cm}\end{array}$ & $\begin{array}{l}417 \mathrm{D}-64-2, \\
128-130 \mathrm{~cm}\end{array}$ & $\begin{array}{c}418 \mathrm{~A}-46-1, \\
46-49 \mathrm{~cm}\end{array}$ & $\begin{array}{c}418 \mathrm{~A}-50-1 \\
136 \mathrm{~cm}\end{array}$ & $\begin{array}{c}418 \mathrm{~A}-50-5 \\
79 \mathrm{~cm}\end{array}$ & $\begin{array}{c}418 \mathrm{~A}-52-4 \\
6-8 \mathrm{~cm}\end{array}$ & $\begin{array}{r}418 \mathrm{~A}-55-2 \\
29-33 \mathrm{~cm}\end{array}$ \\
\hline $\mathrm{SiO}_{2}$ & 51.56 & 50.20 & 49.96 & 49.73 & 49.71 & 49.88 & 50.25 & 50.36 \\
\hline $\mathrm{TiO}_{2}$ & 1.35 & 1.79 & 1.64 & 1.22 & 1.25 & 1.23 & 1.33 & 1.79 \\
\hline $\mathrm{Al}_{2} \mathrm{O}_{3}$ & 15.19 & 13.65 & 14.08 & 14.95 & 15.57 & 14.99 & 14.61 & 13.86 \\
\hline $\mathrm{FeO}^{\mathrm{b}}$ & 9.21 & 12.03 & 11.56 & 10.22 & 10.26 & 10.20 & 10.62 & 11.99 \\
\hline $\mathrm{MnO}$ & 0.17 & 0.22 & 0.21 & 0.19 & 0.18 & 0.19 & 0.20 & 0.21 \\
\hline $\mathrm{MgO}$ & 8.12 & 6.99 & 7.29 & 8.14 & 8.23 & 8.06 & 7.79 & 6.94 \\
\hline $\mathrm{CaO}$ & 11.46 & 11.42 & 11.42 & 12.34 & 12.48 & 12.37 & 12.28 & 11.56 \\
\hline $\mathrm{Na}_{2} \mathrm{O}$ & 2.66 & 2.38 & 2.39 & 2.27 & 2.13 & 2.28 & 2.32 & 2.38 \\
\hline $\mathrm{K}_{2} \mathrm{O}$ & 0.09 & 0.09 & 0.11 & 0.07 & 0.07 & 0.07 & 0.08 & 0.09 \\
\hline $\mathrm{P}_{2} \mathrm{O}_{5}$ & 0.13 & 0.14 & 0.13 & 0.09 & 0.09 & 0.09 & 0.10 & 0.14 \\
\hline & 0.107 & 0.153 & 0.145 & 0.127 & 0.122 & 0.127 & 0.130 & 0.153 \\
\hline Total & 100.05 & 99.06 & 98.94 & 99.35 & 100.09 & 99.49 & 99.71 & 99.47 \\
\hline
\end{tabular}

${ }^{\mathrm{a}}$ Interlaboratory standard (see Staudigel, this volume).

$\mathrm{b}_{\text {Total }} \mathrm{Fe}$ as FeO.

c Glass selvage of small "dike" (Sub-unit 15A).

\section{Silicate Petrography}

Both flows are petrographically similar, having the phenocryst assemblage plagioclase $(<10 \%, 2$ to $8 \mathrm{~mm})$, clinopyroxene $(<5 \%,<2 \mathrm{~mm})$, and olivine $(<1$ to $5 \%, \leqslant 1$ $\mathrm{mm})$. Olivine phenocrysts are euhedral and largely replaced by smectite, except near the base of Sub-unit 14C (Sections 418A-84-4 to 418A-85-7), where fresh grains remain. Their abundances gradually increase from $\sim 1$ per cent at the top to $\sim 5$ per cent near the base of $14 \mathrm{C}$, presumably reflecting accumulation.

Clinopyroxenes occur as rounded oikocrysts or in subophitic anhedral plates with feldspar. Plagioclase phenocrysts are euhedral to subhedral and contain numerous devitrified glass inclusions. The groundmass ranges from variolitic at the flow margins to a coarse-grained (0.5-1 $\mathrm{mm}$ ), subophitic texture in the interiors and contains clinopyroxene and plagioclase in the ratio of $\sim 1: 1$. The groundmass also contains a very fine-grained mesostasis which is interstitial to subophitic regions, comprises 10 to 25 per cent of the rock, and represents the last interstitial melt. The mesostasis is composed of primary silicate phases, usually partially altered to clays, and also contains nearly all of the oxides and sulfides present in the rock. With the exception of alteration of the olivines and of the mesostasis, the rocks of these flows are fresh.

\section{Oxides}

Oxides comprise 4 to 5 per cent of the flows and appear as euhedral to skeletal crystals in the mesostasis. The primary magmatic oxides are ulvospinel and ilmenite; however, the latter is observed in discrete needles only in flow interiors, is much less abundant than ulvospinel, and therefore began crystallizing at lower temperatures. Ulvospinels are generally homogeneous, but in some samples (from more slowly cooled parts of flows) they exhibit trellis-type ilmenite oxidation "exsolution" (Haggerty, 1976). More oxidized mineral assemblages are not observed. Detailed study of the oxide phase relations in these flows is in progress and will be reported elsewhere.

\section{SULFIDE PETROGRAPHY}

\section{Assemblages}

Sulfides have been observed in all samples from the thick flows of Hole 418A. They consist of spherical to subspherical globules resembling those observed in glasses of quenched pillow rims which represent the immiscibility of sulfide-oxide and silicate liquids. In addition, secondary sulfides are observed in association with smectite and calcite or as replacements in the rock matrix. The latter are mainly pyrites with subordinate chalcopyrites, whereas globules and other grains exhibiting primary features consist of pyrrhotite, chalcopyrite, and probably intermediate solid solution sulfides (iss). In two samples (from Section 418A-79-1), all primary sulfides have been recrystallized to the pyrite-chalcopyrite assemblage. Although pyrites and pyrrhotites may each be present in the same sample, they are never observed to occur together. Thus, there are two assemblages, pyrite-chalcopyrite and pyrrhotite-chalcopyrite-iss sulfides, which are texturally as well as mineralogically distinct.

Small quantities of $\mathrm{Ni}$-rich sulfides are present as intergrowths in some Cu-bearing phases, but none have been found large enough for quantitative analysis.

\section{Sulfide Globules}

The fine-grained rapidly quenched flow margins contain delicate skeletal ulvospinel crystals and numerous globules (Plate 1, Figure 1). Globules increase in size and decrease in number toward coarser flow interiors. For example, in the quenched basalt of Plate 1, Figure 1, which has a coarse variolitic texture, globules are generally $<2 \mu \mathrm{m}$ wide and attain maximum diameters of $\sim 10 \mu \mathrm{m}$. In subophitic flow interiors, where silicate grain sizes are on the order of 0.5 to $1 \mathrm{~mm}$, globule diameters are typically 10 to $15 \mu \mathrm{m}$ with the largest up to $100 \mu \mathrm{m}$.

As noted above, nearly all oxides and sulfides are restricted to the fine-grained mesostasis (Plate 1, Figure 2). The restriction extends not only to globule sulfides but also 
TABLE 1 - Continued

\begin{tabular}{|c|c|c|c|c|c|c|c|c|}
\hline & $\begin{array}{c}418-\mathrm{A}-57-5 \\
13-17 \mathrm{~cm}\end{array}$ & $\begin{array}{l}418 \mathrm{~A}-59-5, \\
100-104 \mathrm{~cm}\end{array}$ & $\begin{array}{c}418 \mathrm{~A}-67-2 \\
16-18 \mathrm{~cm}\end{array}$ & $\begin{array}{r}418 \mathrm{~A}-70-2, \\
80-84 \mathrm{~cm}\end{array}$ & $\begin{array}{r}418 \mathrm{~A}-71-4 \\
73-76 \mathrm{~cm}\end{array}$ & $\begin{array}{c}418 \mathrm{~A}-75-5 \\
4-8 \mathrm{~cm}\end{array}$ & $\begin{array}{r}418 \mathrm{~A}-79-4^{\mathrm{c}} \\
83-86 \mathrm{~cm}\end{array}$ & $\begin{array}{r}418 \mathrm{~B}-35-2, \\
90-93 \mathrm{~cm}\end{array}$ \\
\hline $\mathrm{SiO}_{2}$ & 50.13 & 50.21 & 50.46 & 50.66 & 50.52 & 50.66 & 50.83 & 50.62 \\
\hline $\mathrm{TiO}_{2}^{2}$ & 1.65 & 1.73 & 1.57 & 1.56 & 1.53 & 1.47 & 1.56 & 1.24 \\
\hline $\mathrm{Al}_{2} \mathrm{O}_{3}$ & 13.99 & 14.16 & 13.82 & 13.69 & 13.76 & 13.72 & 13.80 & 14.51 \\
\hline $\mathrm{FeO}^{\mathrm{b}}$ & 11.59 & 11.75 & 11.33 & 11.29 & 11.29 & 11.08 & 11.43 & 10.15 \\
\hline $\mathrm{MnO}$ & 0.20 & 0.21 & 0.21 & 0.20 & 0.21 & 0.20 & 0.21 & 0.18 \\
\hline $\mathrm{MgO}$ & 7.20 & 7.06 & 7.20 & 7.24 & 7.23 & 7.39 & 7.34 & 7.82 \\
\hline $\mathrm{CaO}$ & 11.75 & 11.63 & 11.69 & 11.71 & 11.77 & 11.62 & 11.97 & 12.30 \\
\hline $\mathrm{Na}_{2} \mathrm{O}$ & 2.40 & 2.46 & 2.37 & 2.38 & 2.36 & 2.33 & 2.37 & 2.31 \\
\hline $\mathrm{K}_{2}{ }_{2}^{\mathrm{O}}$ & 0.11 & 0.13 & 0.10 & 0.10 & 0.10 & 0.11 & 0.10 & 0.09 \\
\hline $\mathrm{P}_{2} \mathrm{O}_{5}$ & 0.14 & 0.15 & 0.14 & 0.13 & 0.13 & 0.12 & 0.14 & 0.10 \\
\hline & 0.147 & 0.150 & 0.145 & 0.140 & 0.141 & 0.136 & 0.140 & 0.125 \\
\hline Total & 99.31 & 99.64 & 99.04 & 99.10 & 99.04 & 98.84 & 99.89 & 99.45 \\
\hline
\end{tabular}

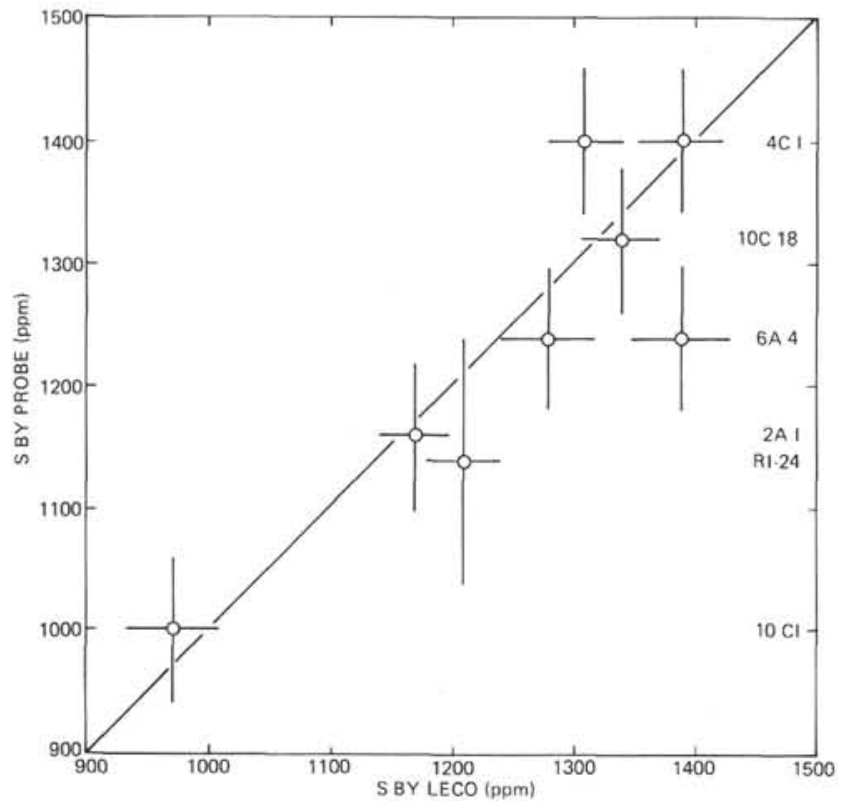

Figure 1. Comparison of $S$ concentrations in basalt glass test samples by probe and by the LECO method in nonDSDP glasses (Delaney, 1977). Numbers on right identify samples. Note that for Samples $4 C 1$ and $6 A 4$ there are two LECO analyses each.

to $\mathrm{Cu}$-rich sulfide-pyrrhotite grains which possess irregular shapes. The exceptions are the rare globules, sometimes with devitrified glass, enclosed as inclusions in plagioclase phenocrysts, and pyrites which are obviously secondary replacement products (e.g., vein fillings).

Globules in the quenched rocks of flow margins are concentrated in and around skeletal oxides (Plate 1, Figure 1). Similarly, there is a distinct spatial association of sulfides and ulvospinels in flow interiors, where sulfides exhibit an interstitial relationship with oxides (Plate 1, Figure 3) and are frequently observed as subspherical inclusions in them (Plate 1, Figure 4). The association of globules and oxides is an expected consequence of the two phases separating simultaneously from a silicate liquid. This occurs because oxide crystallization will decrease $\mathrm{Fe}$ concentrations in residual silicate liquids and thus drive such liquids to $\mathrm{FeS}$ supersaturation (Figure 2).

Many globules have high $\mathrm{Ti}$ oxide rims such as those shown in Plate 2, Figures 1 and 2. Therefore, the rims are probably of similar composition to the ulvospinels that crystallized from the silicate liquid and are not the relatively pure magnetite which would crystallize from droplets of sulfide-oxide liquid. Oxide rims are only partially developed around globules, and some globules have no such rims. Thus, the textures do not support the contention of Ade-Hall et al. (1976) that they result from some reaction of sulfide and silicate phases. Rather, oxide rims may originate by their crystallization from silicate liquid on nucleation centers provided by the sulfides.

Nearly all globules from flow interiors have irregular edges with numerous silicate embayments, as well as inclusions of silicates and magnetite (Plate 2, Figures 3 and 4). Silicate inclusions may make up over 10 per cent of a globule; because of their small size, however, identification of the specific phases is not possible. This contrasts with the lack of such inclusions in typical globules of submarine glasses, implying that much of the silicate is trapped in the sulfide-oxide droplet during its growth. It should be noted that MacLean's (1969) investigation of liquidus relations in the $\mathrm{FeS}-\mathrm{FeO}-\mathrm{SiO}_{2}$ system demonstrates that sulfide-oxide liquid in equilibrium with silicate liquid can dissolve considerable quantities of $\mathrm{Si}$ (the solubility depending on composition and temperature). It is doubtful, however, that the solution of $\mathrm{Si}$ in sulfide-oxide liquid under the conditions of a crystallizing basalt is sufficiently large to account for the observed volume of enclosed silicate material.

Minute magnetite inclusions are also ubiquitous. Those large enough for analysis are essentially pure magnetite, suggesting that such inclusions crystallized from the sulfide-oxide liquid.

Pyrrhotite is far the dominant phase in globules. The $\mathrm{Cu}$-rich sulfides appear as discrete anhedral grains within the globules or as partial rims around pyrrhotite.

As is implicit in the preceding discussion, the textural observations argue for a primary magmatic origin for sulfide 


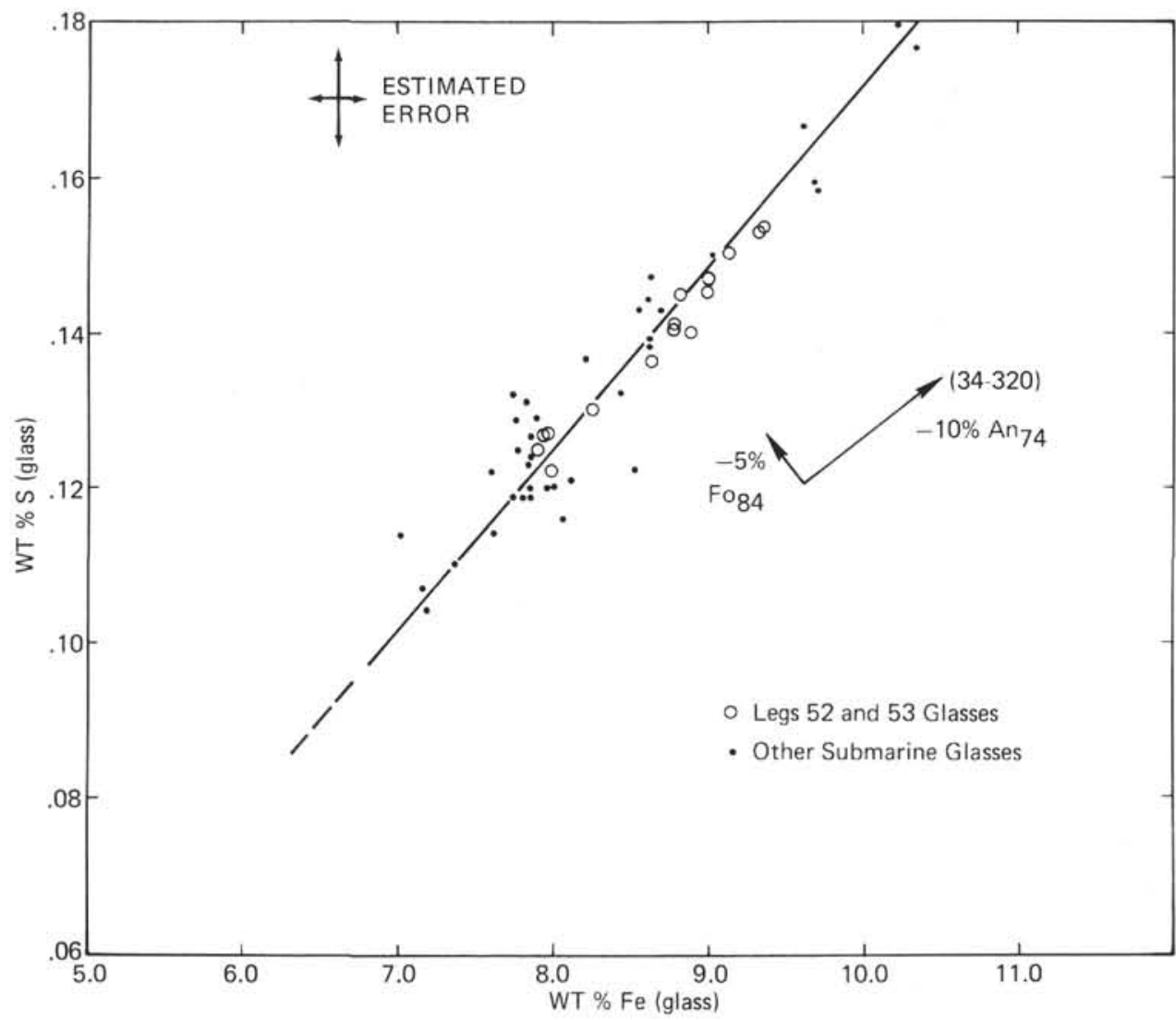

Figure 2. Comparison of $S$ and Fe concentrations in glasses from Holes $417 D, 418 \mathrm{~A}$, and $418 B$ with those of other submarine basalt glasses. The least-squares fit through all data is $S=-0.059+0.023 \mathrm{Fe}$. See discussion in text. The arrows show liquid trends resulting from fractionation of 5 per cent olivine and 10 per cent plagioclase of the compositions indicated using as an example a glass from Hole 320, Leg 34 (cf. Mathez, 1976, fig. 6) with an Fe content of 7.9 per cent (displaced to higher Fe so as not to interfere with $\mathrm{Fe}-\mathrm{S}$ data).

globules. Furthermore, their habit (i.e., their presence in the mesostasis and absence elsewhere) and gradation in size are the predicted results of Figure 2. That is, even in liquids which erupted in a sulfide-saturated state, as the Hole 418A lavas apparently did, the bulk of sulfide separation occurred during late-stage crystallization.

\section{Recrystallized Primary Sulfides}

While many sulfide grains in the Hole 418A lavas exhibit all the characteristics of globules, there are many more which exhibit less well-defined features. In fact, the sulfides exhibit a remarkable textural gradation. At the one extreme, in the freshest basalts, many of the globule features described above are observed. In contrast, rocks that are slightly altered generally lack globules but contain anhedral, irregularly shaped grains of the pyrrhotite-bearing assemblage. The latter have fewer and larger magnetite and silicate inclusions and, in some instances, lack them completely. Furthermore, they are restricted to the rock mesostasis, are interstitial to oxides and the primary unaltered silicate which makes up the non-mesostasis portion of the rock, and exhibit relatively coarse internal sulfide textures. The $\mathrm{Cu}$-bearing phase is usually present as a well developed rim on pyrrhotite. Some of these features are illustrated in Plate 3. The textural gradation between globules and such sulfides and the similarities in assemblage and distribution in the rock indicate that the irregular grains are simply recrystallized globules and primary in the sense that they are not introduced material.

\section{Pyrite-Chalcopyrite Assemblage}

Pyrites with or without chalcopyrites are common constituents of calcite-smectite veins, where the sulfides are present as linings along the vein-rock interface. Pyrites are more rarely observed as discrete euhedra within the veins and as linings in smectite- or calcite-filled vesicles.

Masses of pyrite may also be found in the rock matrix, where they appear as fine-grained intergranular replacements (Plate 4, Figure 1). The one sample studied where such replacements are common lacks globules. Note the euhedral nature of the oxides in Plate 4, Figure 1. These are ulvospinels, i.e., quenched magmatic products not related to reactions responsible for pyrite deposition.

Two of the flow samples $(418 \mathrm{~A}-79-1,39-41 \mathrm{~cm}$ and 418A-79-1, 117-119 cm) are unique. Their oxides exhibit extensive and well-developed volume change cracks, 
interpreted as resulting from low-temperature oxidation (Ade-Hall et al., 1976; H.P. Johnson, personal communication), and the sulfides consist of pyrite with subordinate chalcopyrite having granular and irregular to subhedral shapes. Chalcopyrites are usually present as large (up to 30 $\mu \mathrm{m})$ inclusions in pyrites. However, some have morphologies suggestive of globules. Note, for example, the subspherical shape of the grain in Plate 4, Figure 2, particularly its partial oxide rim and the replacement pyrite extending beyond the former globule boundary. Implicit in the suggestion that such features were globules is that they were originally pyrrhotites (dictated by high temperature equilibria in the Fe-S system and between sulfide oxide and silicate liquids). The interpretation is that slightly higher conditions of $f_{52}$ were imposed on this portion of the flow relative to the rest of the section in the low-temperature hydrothermal environment, resulting in recrystallization and partial solution of existing primary sulfides.

\section{SULFIDE PHASE CHEMISTRY}

\section{Cu-Rich Sulfides}

Selected analyses of Cu-bearing sulfides are presented in Table 2 and Figure 3.

The Cu-rich sulfides are difficult to analyze because sufficiently large grains are rare and because they are always intimately mixed with a silicate phase (Plate 3, Figures 1 to 3 ). Some analyses also contain appreciable quantities of Ni (e.g., Analysis 15 in Table 2). A discrete $\mathrm{Ni}$ sulfide phase does exist in some samples; however, attempts to resolve it have been unsuccessful, and in many grains $\mathrm{Ni}$ may simply exist in solid solution in the $\mathrm{Cu}$-rich sulfides.

It is evident from Figure 3 that the Cu-sulfides fall in the chalcopyrite solid solution field and in the fields of chalcopyrite-iss or chalcopyrite-iss-pyrrhotite stabilities. Even though pyrite and pyrrhotite do not coexist, the fact that chalcopyrites do occur with each indicates differing temperature or compositional conditions of equilibration for the two assemblages. If the $300^{\circ} \mathrm{C}$ phase relations of Figure 3 approximate those in the rock, then some of the plotted analyses apparently reflect unresolvable mixtures of $\mathrm{Cu}$ bearing phases. In one instance, two $\mathrm{Cu}$-sulfides were actually observed in juxtaposition (Analyses 38 and 39 in Table 2); even in this case, their compositions as well as their optical appearance suggest that they are mixtures. Because of the difficulties of resolving $\mathrm{Cu}$-bearing phases and because $\mathrm{Cu}$-sulfides more $\mathrm{Fe}$-rich than chalcopyrite occur with pyrrhotite and not with pyrite, all $\mathrm{Fe}$-rich $\mathrm{Cu}$-sulfides are interpreted as belonging to the pyrrhotite assemblage even though they appear to have undergone an internal equilibration independent of pyrrhotite. In other words, the two assemblages are defined by the presence of pyrite or of pyrrhotite rather than by the specific compositions of the Cu-bearing phases.

In their experimental study of phase relations in the $\mathrm{Cu}-\mathrm{Fe}-\mathrm{S}$ system, Sugaki et al. (1975) note the reaction iss + py $\rightarrow$ po + ccp proceeds at $\leqslant 328^{\circ} \mathrm{C}$, so that the assemblage po + iss + ccp becomes stable. Therefore, the observed assemblages in the Hole 418A lavas indicate sulfide equili- bration below this temperature. Because their fine textures are unresolvable, however, it is not really meaningful to speculate further on equilibration temperature. The presence of fine exsolutions having compositions consistent with those in Figure 3 does indicate, however, the unmixing of Cu-rich sulfides from relatively high temperature $\left(\geqslant 400^{\circ} \mathrm{C}\right)$ phases (cf. Cabri, 1973).

Other phases more Cu-rich than chalcopyrite, such as bornite or idaite, have not been observed.

\section{Pyrrhotite}

Analysis of pyrrhotite is also difficult because of small grain sizes and numerous inclusions of magnetite, silicates, and other sulfide phases. For example, nearly all analyses contain small quantities of $\mathrm{Si}$ (Table 2), and low totals usually correlate with low $\mathrm{S}$ contents. The data have been edited on the basis of totals and Si contents. It is conceivable, of course, that such a procedure introduces a systematic bias in the results.

Edited pyrrhotite compositions exhibit remarkable uniformity throughout both flows, with S contents generally in the range 39.3 to $39.7 \mathrm{wt}$. per cent (Figure 4). Concentrations of $\mathrm{Cu}$ are usually $<0.1$ wt. per cent, and $\mathrm{Ni}$ contents are typically in the range 0.5 to $0.8 \mathrm{wt}$. per cent (Table 2).

The composition of Hole 418A pyrrhotites does not allow unique interpretation of thermal equilibration. For example, the phase diagram of Scott and Kissin (1973) for the central portion of the Fe-S system suggests that projection of the pyrite-pyrrhotite solvus from high temperatures on a plot of $1 / \mathrm{T}$ versus $\log \mathrm{f}_{\mathrm{s}_{2}}$ (Figure 5) is valid to $265^{\circ} \mathrm{C}$. Above this temperature, pyrrhotite isopleths (as shown on Figure 5) intersect the solvus such that a pure $\mathrm{Fe}-\mathrm{S}$ pyrrhotite containing 39.5 wt. per cent $\mathrm{S}$ (the average value for Hole $418 \mathrm{~A}$ sulfides) is not stable below $\sim 426^{\circ} \mathrm{C}$, corresponding to $\mathrm{f}_{\mathrm{s}_{2}} \sim 10^{-6.3}$. It should be noted that the experimental error in determination of the solvus, the projection of isopleths below the temperature range over which they have been measured, the relative orientation of these curves on Figure 5 , and the accuracy of probe analysis all combine to produce large uncertainty in such a temperature estimate. Figure 5, however, permits interpretation of the most S-rich pyrrhotites in terms of their equilibration at relatively high temperatures.

On the other hand, pyrrhotites in equilibrium with pyrite below $265^{\circ} \mathrm{C}$ become more S-rich, and the projected solvus must change slope because of modifications in the pyrrhotite structure. The low-temperature solvus (Figure 5) is drawn to satisfy geometric constraints imposed by the phase diagram of Scott and Kissin (1973); however, it is schematic in that the slopes of its various segments cannot be determined. According to Morimoto et al. (1975), there are four distinct low-temperature pyrrhotites in addition to troilite $(\mathrm{FeS})$. They can be described by the general formula $\mathrm{Fe}_{\mathrm{n}-1} \mathrm{~S}_{\mathrm{n}}$, where $\mathrm{n} \geqslant 8$, and thus include the common monoclinic variety, $\mathrm{Fe}_{7} \mathrm{~S}_{8}(39.6$ wt. \% S), as well as other structural types in the range $\mathrm{Fe}_{9} \mathrm{~S}_{10}$ to $\mathrm{Fe}_{11} \mathrm{~S}_{12}$ (39.0 to 38.5 wt. $\% \mathrm{~S})$. Therefore, it is also possible that the sulfides equilibrated at very low temperatures.

It is well established that high-temperature pyrrhotites may contain considerable quantities of $\mathrm{Cu}$ in solid solution. 
TABLE 2

Selected Microprobe Analyses ${ }^{\mathrm{a}}$ of Sulfides in Flows from Hole 418A

\begin{tabular}{|c|c|c|c|c|c|c|c|c|c|c|}
\hline $\begin{array}{l}\text { Analysis } \\
\text { Number }\end{array}$ & $\begin{array}{c}\text { Sample } \\
\text { (Interval in } \mathrm{cm} \text { ) }\end{array}$ & Phase $^{\mathrm{b}}$ & S & $\mathrm{Fe}$ & $\mathrm{Cu}$ & $\mathrm{Ni}$ & Co & $\mathrm{Si}$ & Total & Notes \\
\hline 1 & $76-2,54-56$ & Py & 53.18 & 46.62 & 0.00 & 0.01 & - & - & 99.82 & Vesicle lining \\
\hline 2 & $76-2,54-56$ & Py & 53.09 & 44.89 & 0.03 & 1.27 & - & - & 99.29 & Replacement, similar to Plate 4, Figure 1 \\
\hline 3 & $76-2,54-56$ & Py & 52.98 & 46.14 & 0.00 & 0.22 & - & - & 99.35 & Replacement, similar to Plate 4, Figure 1 \\
\hline 4 & $76-2,54-56$ & $\mathrm{Cu}$ & 34.25 & 28.96 & 34.17 & 0.06 & - & - & 97.44 & Angular grain in plagioclase \\
\hline 5 & $77-2,54-56$ & $\mathrm{Py}$ & 53.26 & 46.43 & 0.00 & 0.01 & - & - & 99.71 & Replacement, similar to Plate 4, Figure 1 \\
\hline 6 & $77-2,54-56$ & $\mathrm{Cu}$ & 34.14 & 29.01 & 34.21 & 0.78 & - & - & 98.14 & $10-\mu \mathrm{m}$ fragment in mesostasis \\
\hline 7 & $77-4,58-60$ & Po & 39.66 & 59.52 & 0.00 & 0.58 & - & - & 99.76 & Globule, $<20-\mu \mathrm{m}$ diameter \\
\hline 8 & $77-4,58-60$ & Po & 40.08 & 59.38 & 0.01 & 0.55 & - & - & 100.01 & Irregular grain \\
\hline 9 & $77-4,58-60$ & Po & 39.43 & 58.87 & 0.01 & 0.67 & - & - & 98.98 & Globule, $<20-\mu \mathrm{m}$ diameter \\
\hline 10 & $77-4,58-60$ & Po & 39.39 & 59.00 & 0.00 & 0.55 & - & - & 98.94 & Average of 10 selected globule analyses \\
\hline 11 & $77-4,58-60$ & Py & 52.19 & 46.55 & 0.00 & 0.04 & - & - & 98.78 & \\
\hline 12 & $78-2,114-116$ & Po & 39.68 & 59.68 & 0.06 & 0.45 & - & - & 99.86 & Irregular-shaped globule, $<20 \mu \mathrm{m}$ \\
\hline 13 & $78-2,114-116$ & Py & 52.18 & 46.38 & 0.00 & 0.03 & - & - & 98.59 & \\
\hline 14 & $78-2,114-116$ & Po & 39.36 & 58.32 & 0.06 & 0.78 & - & - & $98.51\}$ & 2 phase incl in plagioclase \\
\hline 15 & $78-2,114-116$ & $\mathrm{Cu}+\mathrm{Ni}$ & 33.44 & 28.49 & 27.06 & 7.24 & - & - & $96.24\}$ & 2 prlase inci, in plagiociase \\
\hline 16 & $79-1,39-41$ & Py & 52.98 & 45.98 & 0.03 & 0.28 & - & 0.21 & 99.48 & \\
\hline 17 & $79-4,83-86$ & Po & 39.38 & 59.60 & 0.02 & 0.88 & 0.02 & 0.06 & 99.96 & Average of 4 spherical globules, $>15 \mu \mathrm{m}$ \\
\hline 18 & $79-4,83-86$ & Po & 39.49 & 59.92 & 0.08 & 0.76 & 0.03 & 0.02 & 100.30 & Globule, Plate 2, Figure 3 \\
\hline 19 & $79-4,83-86$ & Po & 39.51 & 60.20 & 0.04 & 0.67 & 0.05 & 0.03 & 100.50 & Globule, Plate 1, Figure 3 \\
\hline 20 & $79-4,83-86$ & Po & 38.94 & 59.39 & 0.07 & 0.69 & 0.03 & 0.00 & 99.12 & Globule in mag, Plate 1, Figure 4 \\
\hline 21 & $79-4,83-86$ & Po & 39.37 & 59.50 & 0.04 & 0.69 & 0.02 & 0.01 & 99.62 & Globule, $30 \mu \mathrm{m}$, average of 3 points \\
\hline 22 & $79-4,83-86$ & Po & 39.91 & 60.38 & 0.08 & 0.68 & 0.04 & 0.02 & 101.11 & Globule, $30 \mu \mathrm{m}$ \\
\hline 23 & $79-4,83-86$ & Py & 52.76 & 46.46 & 0.03 & 0.01 & 0.00 & 0.00 & 99.26 & Euhedral py in calcite + smectite vein \\
\hline 24 & $79-4,83-86$ & Py & 52.68 & 45.89 & 0.13 & 0.96 & 0.14 & 0.08 & $99.88\}$ & 2-phase irreoular orain in mesestasis \\
\hline 25 & $79-4,83-86$ & $\mathrm{Cu}+\mathrm{Ni}(?)$ & 34.76 & 30.85 & 26.45 & 1.70 & 1.07 & 0.63 & 95.46 s & 2-phase irregular grain in mesostasis \\
\hline 26 & $79-4,83-86$ & $\mathrm{Cu}$ & 34.89 & 30.51 & 35.10 & 0.06 & 0.08 & 0.00 & 100.63 & Irregular grain, with po \\
\hline 27 & $79-4,83-86$ & $\mathrm{Cu}$ & 34.29 & 29.30 & 35.17 & - & - & 0.44 & 99.21 & \\
\hline 28 & $79-6,58-60$ & $\mathrm{Py}$ & 52.95 & 46.41 & 0.00 & 0.00 & - & - & 99.36 & Euhedral py in calcite vein \\
\hline 29 & $81-1,68-70$ & Po & 39.54 & 59.56 & 0.23 & 0.62 & - & 0.08 & 100.05 & Globule $>10 \mu \mathrm{m}$ \\
\hline 30 & $81-1,68-70$ & Po & 39.26 & 59.07 & 0.12 & 0.64 & - & 0.25 & 99.34 & Globule $<10 \mu \mathrm{m}$ \\
\hline 31 & $82-1,85-87$ & Po & 39.34 & 59.90 & 0.09 & 0.36 & - & 0.07 & 99.82 & Globule $>20 \mu \mathrm{m}$ \\
\hline 32 & $82-1,85-87$ & Po & 39.52 & 59.79 & 0.03 & 0.35 & - & 0.08 & 99.77 & Average of 6 selected globule analyses \\
\hline 33 & $83-2,116-118$ & Po & 39.30 & 59.75 & 0.09 & 0.36 & - & 0.07 & $99.57\}$ & 2-phase globule \\
\hline 34 & $83-2,116-118$ & $\mathrm{Cu}$ & 34.68 & 36.73 & 28.59 & 1.58 & - & 0.12 & 100.51 & \\
\hline 35 & $83-2,116-118$ & Po & 39.38 & 59.78 & 0.16 & 0.25 & - & 0.10 & 99.67 & Globule \\
\hline 36 & $83-2,116-118$ & Po & 39.38 & 59.85 & 0.09 & 0.36 & - & 0.08 & 99.76 & Average of 6 selected globule analyses \\
\hline 37 & $84-2,93-95$ & Po & 39.31 & 59.97 & 0.06 & 0.52 & - & 0.04 & 99.90 & \\
\hline 38 & $84-2,93-95$ & $\mathrm{Cu}$ & 34.53 & 30.44 & 35.28 & 1.02 & - & 0.09 & $101.37\}$ & Globule of po + two distinct $\mathrm{Cu}$ phases \\
\hline 39 & $84-2,93-95$ & $\mathrm{Cu}$ & 34.72 & 31.71 & 33.41 & 1.66 & - & 0.05 & $101.55\}$ & \\
\hline 40 & $84-2,93-95$ & Po & 39.42 & 59.91 & 0.00 & 0.48 & - & 0.07 & 99.88 & Irregular glob with mag incl. \\
\hline 41 & $84-2,93-95$ & $\mathrm{Cu}$ & 34.71 & 30.41 & 33.98 & 0.86 & - & 0.07 & 100.04 & Rim on above \\
\hline 42 & $84-2,93-95$ & $\mathrm{Cu}$ & 34.63 & 30.03 & 36.21 & 0.31 & - & 0.09 & 101.28 & Recrystallized po $+\mathrm{Cu}$ globule \\
\hline 43 & $84-2,93-95$ & Po & 39.37 & 59.93 & 0.02 & 0.48 & - & 0.06 & 99.86 & Average of 5 selected globule analyses \\
\hline 44 & $85-1,118-120$ & $\mathrm{Cu}$ & 35.45 & 37.48 & 26.61 & 1.00 & 0.09 & - & 100.62 & \\
\hline 45 & $85-1,118-120$ & Po & 39.68 & 59.34 & 0.02 & 0.51 & 0.05 & - & 99.62 & Globule, $22 \mu \mathrm{m}$ \\
\hline 46 & $85-1,118-120$ & Po & 39.55 & 60.05 & 0.00 & 0.49 & 0.04 & - & 100.14 & Irregular grain \\
\hline 47 & $85-1,118-120$ & $\mathrm{Cu}$ & 35.58 & 37.86 & 23.33 & 3.01 & 0.22 & - & 101.34 & In contact with above, $\sim 70 \mu \mathrm{m}$ \\
\hline 48 & $85-1,118-120$ & $\mathrm{Cu}$ & 35.33 & 35.91 & 26.99 & 2.55 & 0.32 & - & 101.10 & \\
\hline 49 & $85-1,118-120$ & $\mathrm{Cu}$ & 34.80 & 31.24 & 33.57 & - & - & - & 99.60 & \\
\hline 50 & $85-1,118-120$ & Po & 39.32 & 59.89 & 0.07 & 0.34 & 0.02 & - & 99.64 & \\
\hline 51 & $85-1,118-120$ & Po & 39.34 & 59.72 & 0.03 & 0.44 & 0.04 & - & 99.57 & Average of 11 selected analyses \\
\hline 52 & $85-4,68-70$ & Po & 39.35 & 59.84 & 0.10 & 0.38 & - & 0.04 & 99.71 & Irregular grain, Plate 3, Figure 1 \\
\hline 53 & $85-4,68-70$ & $\mathrm{Cu}+\mathrm{Ni}(?)$ & 32.21 & 31.08 & 25.85 & 3.32 & - & 1.48 & 93.94 & Rim on above, includes silicate \\
\hline 54 & $85-4,68-70$ & Po & 39.55 & 59.90 & 0.04 & 0.47 & - & 0.11 & 100.05 & Globule $<20 \mu \mathrm{m}$ \\
\hline 55 & $85-4,68-70$ & $\mathrm{Cu}+\mathrm{Ni}(?)$ & 33.37 & 28.08 & 28.13 & 6.41 & - & 0.77 & 96.76 & \\
\hline 56 & $85-4,68-70$ & Po & 39.46 & 59.85 & 0.10 & 0.46 & - & 0.08 & 99.95 & Average of 9 selected analyses \\
\hline 57 & $85-7,74-76$ & Po & 39.48 & 60.05 & 0.04 & 0.45 & - & 0.06 & $100.08\}$ & 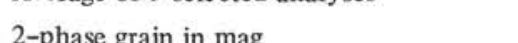 \\
\hline 58 & $85-7,74-76$ & $\mathrm{Cu}+\mathrm{Ni}(?)$ & 35.74 & 32.97 & 25.95 & 3.21 & - & 0.60 & $98.48\}$ & 2-phase grain in mag \\
\hline 59 & $85-7,74-76$ & Po & 39.58 & 59.85 & 0.02 & 0.45 & - & 0.07 & 99.97 & Average of 4 selected analyses \\
\hline
\end{tabular}

a Analytical procedure: $15 \mathrm{kV}$ acceleration potential, $50 \mathrm{nA}$ sample current on troilite, EMPADR VII matrix correction.

Standards: $\mathrm{Fe}, \mathrm{S}=$ meteorite troilite $\mathrm{Cu}=$ synthetic $\mathrm{CuFeS}_{2} ; \mathrm{Ni}=$ synthetic $\mathrm{NiS} ; \mathrm{Co}=$ synthetic $\mathrm{CoS} ; \mathrm{Si}=$ diopside glass.

${ }^{\mathrm{Py}}=$ Pyrite $; \mathrm{Po}=$ pyrrhotite $; \mathrm{Cu}=\mathrm{CuFe}$ sulfide $; \mathrm{Ni}=\mathrm{NiFe}$ sulfide. 


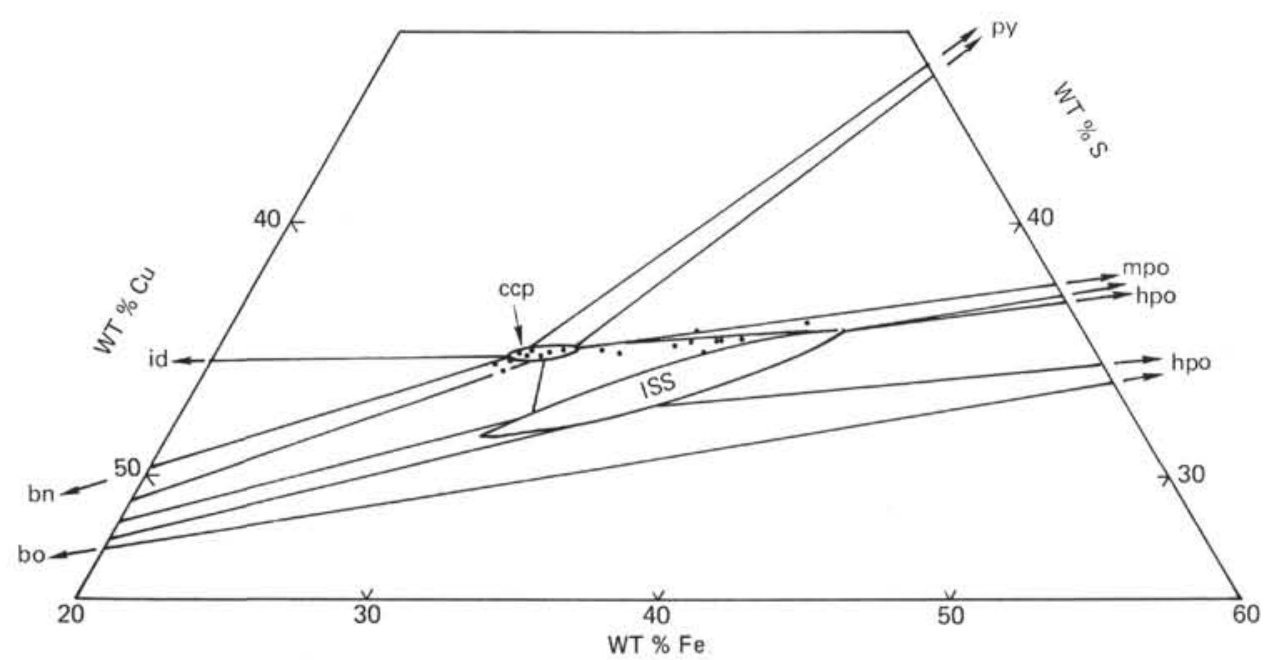

Figure 3. Selected compositions of Cu-bearing sulfides in flows from Hole 418A. Phase relations for the Cu-Fe-S system are at $300^{\circ} \mathrm{C}$ (from fig. 7 of Sugaki et al., 1975). Analyses are plotted by normalizing wt. per cent $(\mathrm{Fe}+\mathrm{Cu})$ to 100 minus wt. per cent $S . C c p=$ chalcopyrite solid solution; iss = intermediate solid solution; $h p o=$ hexagonal pyrrhotite $;$ mo $=$ monoclinic pyrrhotite $;$ py $=$ pyrite $;$ id $=$ idaite $;$ bo $=$ bornite .

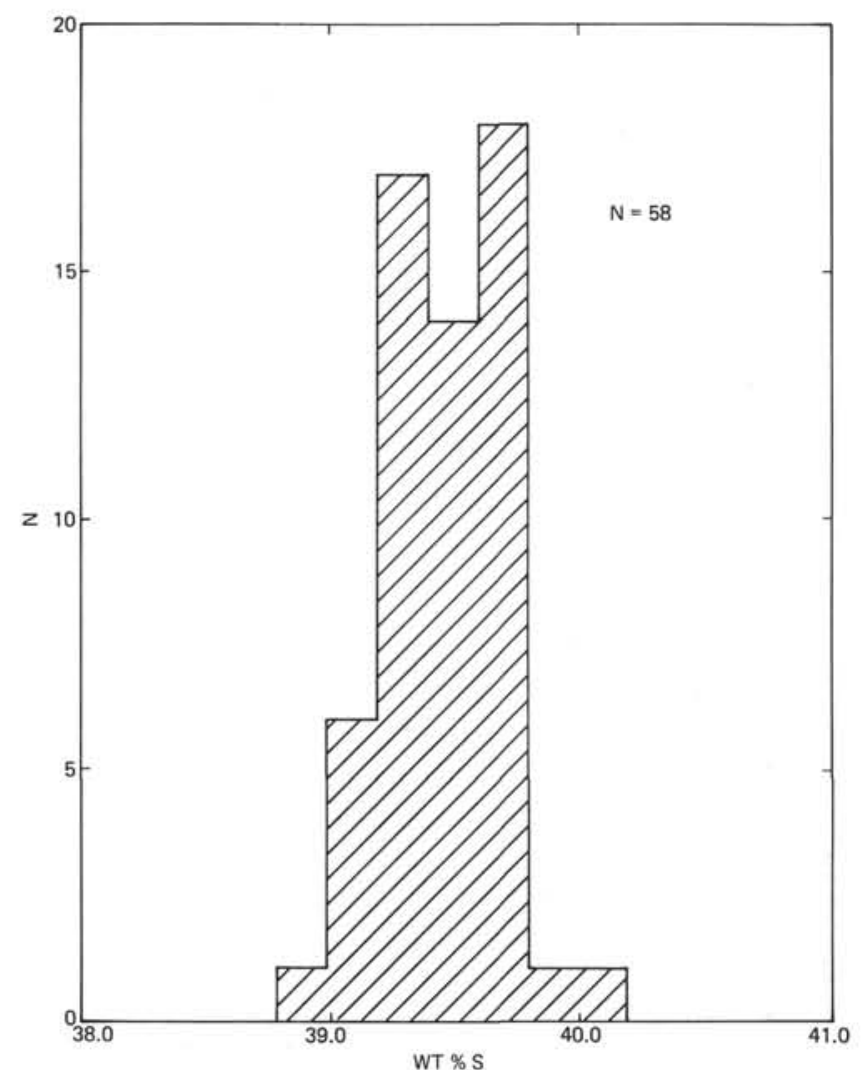

Figure 4. Histogram of $S$ contents of pyrrhotites from Hole $418 \mathrm{~A}$ flows. The error due to counting statistics is $\sim \pm 0.4 w t$. per cent $S(2 \sigma$ value $)$.

For example, the $\mathrm{Cu}$ contents of pyrrhotite in equilibrium with pyrite and iss is $\sim 1.8$ wt. per cent at $600^{\circ} \mathrm{C}$ (Cabri, 1973 ) and $\sim 0.1$ wt. per cent at $350^{\circ} \mathrm{C}$ (Sugaki et al., 1975). Therefore, the low Cu contents of most of the Hole 418A pyrrhotites are consistent with low equilibration temperatures. The data on $\mathrm{Cu}$ in pyrrhotites are insufficient, however to establish whether or not the sulfide reached thermal equilibrium above $300^{\circ} \mathrm{C}$, i.e., during initial cooling of the lava, or in a later low-temperature hydrothermal environment.

\section{Pyrite}

The Ni contents of pyrites exhibit considerable variability. Typically they contain 0.4 wt. per cent $\mathrm{Ni}$, although some have $>1$ per cent $\mathrm{Ni}$ (Analysis 2 in Table 2). Pyrites in veins and lining vesicles usually have no detectable $\mathrm{Ni}$ and contrast with those in the rock matrix (Plate 4), which are frequently found to contain $>0.2 \mathrm{wt}$. per cent $\mathrm{Ni}$. This may indicate that the pyrites represent two generations of sulfide deposition.

\section{SUMMARY AND DISCUSSION OF SULFIDE RELATIONS}

Two mineralogical and textural assemblages are recognized in the thick flows recovered from the base of Hole 418A. The mineralogical distinction is based on whether the Fe-sulfide is pyrrhotite or pyrite. The assemblage containing pyrrhotite exhibits textural gradation from globules, which assumed their form at magmatic temperatures, to irregular grains, which are interpreted as representing primary sulfides recrystallized at much lower temperature. Compositions and phase relations of this assemblage require chemical equilibration at relatively low temperature $\left(<300^{\circ} \mathrm{C}\right)$. Therefore, the textures record a complex history that is not reflected by the chemical relations.

The pyrite-chalcopyrite assemblage is texturally distinct from the primary one. Pyrites with or without chalcopyrites occur in veins, as vesicle linings, and as replacements in the rock mesostasis. However, in two samples from core 


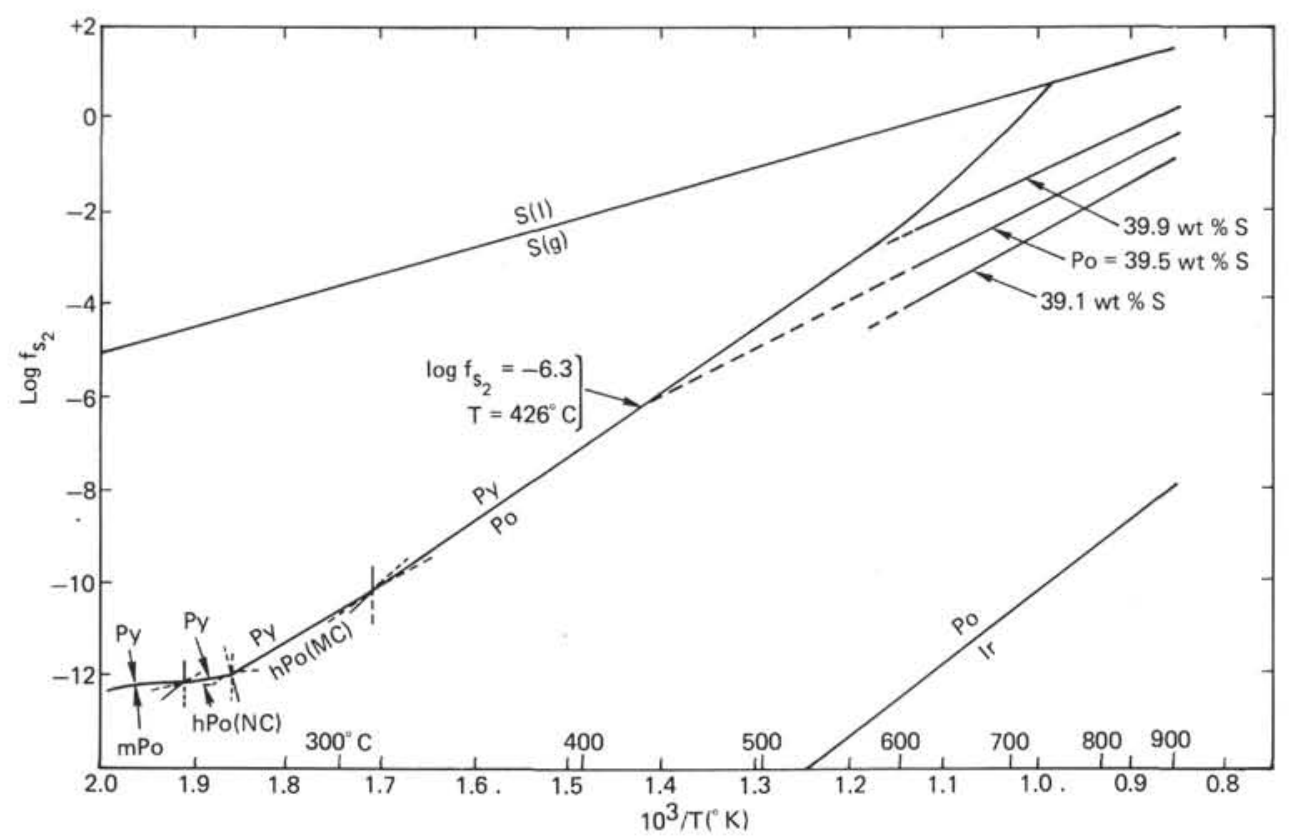

Figure 5. $\log f_{s,}$ versus $1 / T$ for the $\mathrm{Fe}-\mathrm{S}$ system. Pyrrhotite isopleths (light contours, dashed in temperature range beyond their experimental determination) are calculated from the solution model of Froese and Gunter (1976). The hpo-py solvus above $307^{\circ} \mathrm{C}$ is from Scott and Barnes (1971). At lower temperatures, the solvus is based on phase relations in the Fe-S system of Scott and Kissin (1973). Here it is schematic and drawn to satisfy geometric constraints only. The diagram shows that Hole $418 \mathrm{~A}$ pyrrhotites containing $\sim 39.5 \mathrm{wt}$. per cent $S$ may be interpreted to have equilibrated at temperatures $>426^{\circ} \mathrm{C}$ or $<265^{\circ} \mathrm{C}$. See text for discussion. Ir $=$ iron metal; $P$ Po $=$ pyrrhotite; $h P o(M C)=$ "hexagonal" pyrrhotite (MC type); $h P o(N C)=$ "hexagonal" pyrrhotite (NC type); $m P o=$ monoclinic pyrrhotite Py $=$ pyrite.

$418 \mathrm{~A}-79$, the pyrites possess some of the textural characteristics of globules.

Although the textural observations have been interpreted to indicate that most of the present sulfide is primary in the sense that it is not introduced material, this is not to say that low-temperature processes are strictly isochemical. For example, the $\mathrm{Cu}: \mathrm{Ni}$ ratio of sulfide globules in moderately evolved submarine basaltic glasses is commonly in the range of about 1 to 4 (cf. Mathez, 1976; Czamanske and Moore, 1977). Thus, in the Hole 418A lavas, we should expect to observe at least 25 per cent as much Ni-rich sulfide (pentlandite) as Cu-rich sulfide. The paucity of $\mathrm{Ni}$-rich phases suggests that the $\mathrm{Cu}: \mathrm{Ni}$ ratio is much higher than 4. If this is true, and if the magmatic sulfide composition of the Hole 418A rocks was once typical of other submarine basalts, then the Ni-bearing phases must have undergone a redistribution history not shared by other sulfides. It is conceivable that the $\mathrm{Ni}$ originally in magmatic sulfides in these rocks now resides in pyrite or in smectites.

The recognition that submarine basalts contain disseminated magmatic sulfides indicates that the presence or absence of sulfide ore deposits in ocean basins depends primarily on the nature of redistribution processes.

\section{ACKNOWLEDGMENTS}

I am grateful for the critical reviews of the manuscript by J.R. Delaney and I.S. McCallum.

\section{REFERENCES}

Ade-Hall, J.M., Fink, L.K., and Johnson, H.P., 1976. Petrography of opaque minerals, Leg 34. In Yeats, R.S., Hart, S.R., et al., Initial Reports of Deep Sea Drilling Project, v. 34: Washington (U.S. Government Printing Office), p. 349-362.

Barton, P.B., Jr., 1973. Solid solutions in the system $\mathrm{Cu}-\mathrm{Fe}-\mathrm{S}$. Part I: The Cu-S and CuFe-S Joins, Economic Geology, v. 68, p. $455-465$.

Cabri, L.J., 1973. New data on phase relations in the Cu-Fe-S system, Economic Geology, v. 68, p. 443-454.

Czamanske, G.K. and Moore, J.G., 1977. Composition and phase chemistry of sulfide globules in basalt from the Mid-Atlantic Ridge rift valley near $37^{\circ} \mathrm{N}$ lat., Geological Society of America Bulletin, v. 88, p. 587-599.

Delaney, J.R., 1977. Distribution of volatiles in the glassy rims of submarine pillow basalts, $\mathrm{Ph}$. D. Dissertation, University of Arizona, Tucson.

Froese, E. and Gunter, A.E., 1976. A note on the pyrrhotite-sulfur vapor equilibrium, Economic Geology, v. 71, p. 1589-1594.

Haggerty, S.E., 1976. Oxidation of opaque mineral oxides in basalts. In Rumble, D., III (Ed.), Oxide minerals: Mineralogical Society of America Short Course Notes, v. 3.

MacLean, W.H., 1969. Liquidus phase relations in the FeS-FeO$\mathrm{Fe}_{3} \mathrm{O}_{4}-\mathrm{SiO}_{2}$ system, and their application in geology, Economic Geology, v. 64, p. $865-884$.

Mathez, E.A., 1976. Sulfur solubility and magmatic sulfides in submarine basalt glass, Journal of Geophysical Research, v. 81 , p. $4269-4275$. 
Moore, J.G. and Fabbi, B.F., 1971. An estimate of the juvenile sulfur content of basalt, Contributions to Mineralogy and Petrology, v. 33, p. 118-127.

Morimoto, N., Gyobu, A., Mukaiyama, H., and Izawa, E., 1975. Crystallography and stability of pyrrhotites, Economic Geology, v. 70, p. 824-833.

Scott, S.D. and Barnes, H.L., 1971. Sphalerite geothermometry and geobarometry, Economic Geology, v. 66, p. 653-669.
Scott, S.D. and Kissin, S.A., 1973. Sphalerite composition in the $\mathrm{Zn}-\mathrm{Fe}-\mathrm{S}$ system below $300^{\circ} \mathrm{C}$, Economic Geology, v. 68 , p. $475-479$.

Sugaki, A., Shima, H., Kitakaze, A., and Harada, H., 1975. Isothermal phase relations in the system $\mathrm{Cu}-\mathrm{Fe}-\mathrm{S}$ under hydrothermal conditions at $350^{\circ} \mathrm{C}$ and $300^{\circ} \mathrm{C}$, Economic Geology, v. 70 , p. $806-823$. 


\section{PLATE 1}

Figure 1

Figure 3

Figure 4
Sulfide globules (white) and skeletal ulvospinels (gray) in quenched basalt, Sample 418A-79-6, 58-60 $\mathrm{cm}$. Note spatial association of sulfides and oxides. Oil immersion.

Sulfide globules (white) and ulvospinels (light gray) in fine-grained mesostasis (darkest gray), Sample 418A-79-4, 83-86 cm. Large crystals are plagioclase. Reflected light.

Sulfide globule (white) exhibiting interstitial relationship with euhedral ulvospinel (gray), Sample 418A$79-4,83-86 \mathrm{~cm}$. Gray inclusions in the sulfide are magnetite. Analysis 19 in Table 2. Oil immersion.

Sulfide globule (white) included in ulvospinel (gray), Sample 418A-79-4, 83-86 cm. Inclusions in sulfide are silicates. Analysis 20 in Table 2. Oil immersion. 
Plate 1
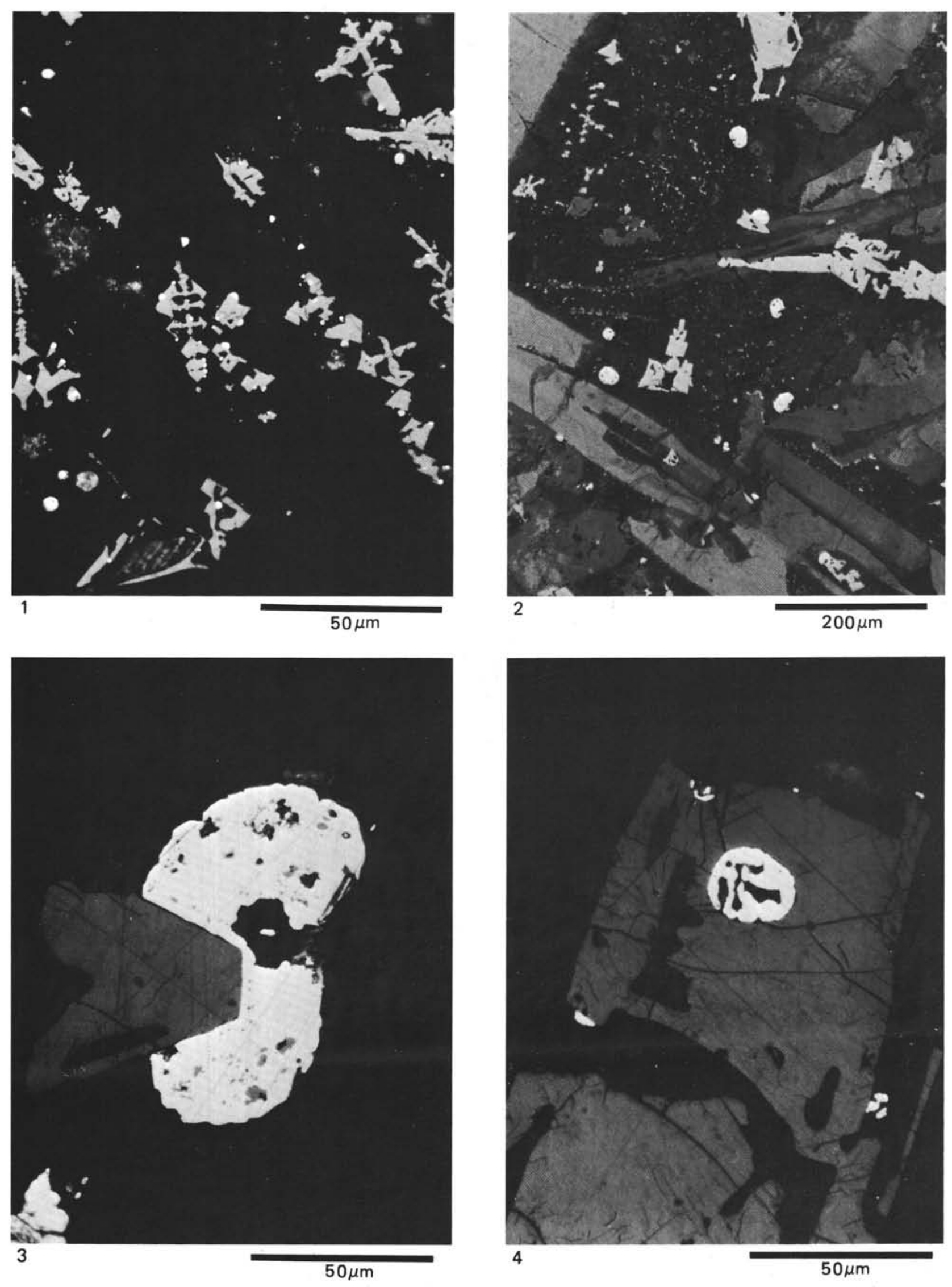


\section{PLATE 2}

Figure $1 \quad$ Enlarged portion of Plate 1, Figure 2, of sulfide globules partially rimmed by ulvospinel. Oil immersion.

Figure 2 Enlarged Ti X-ray beam scanning image of the larger globule of Figure 1.

Figure 3 Sulfide globule containing irregular inclusions of silicate material (dark) and numerous small inclusions of magnetite (light gray), Sample 418A-79-4, 83-86 cm. Analysis 18 in Table 2. Oil immersion.

Figure $4 \quad$ Enlarged Si X-ray beam-scanning image showing distribution of silicate inclusions in the globule of Figure 3. 
PLATE 2

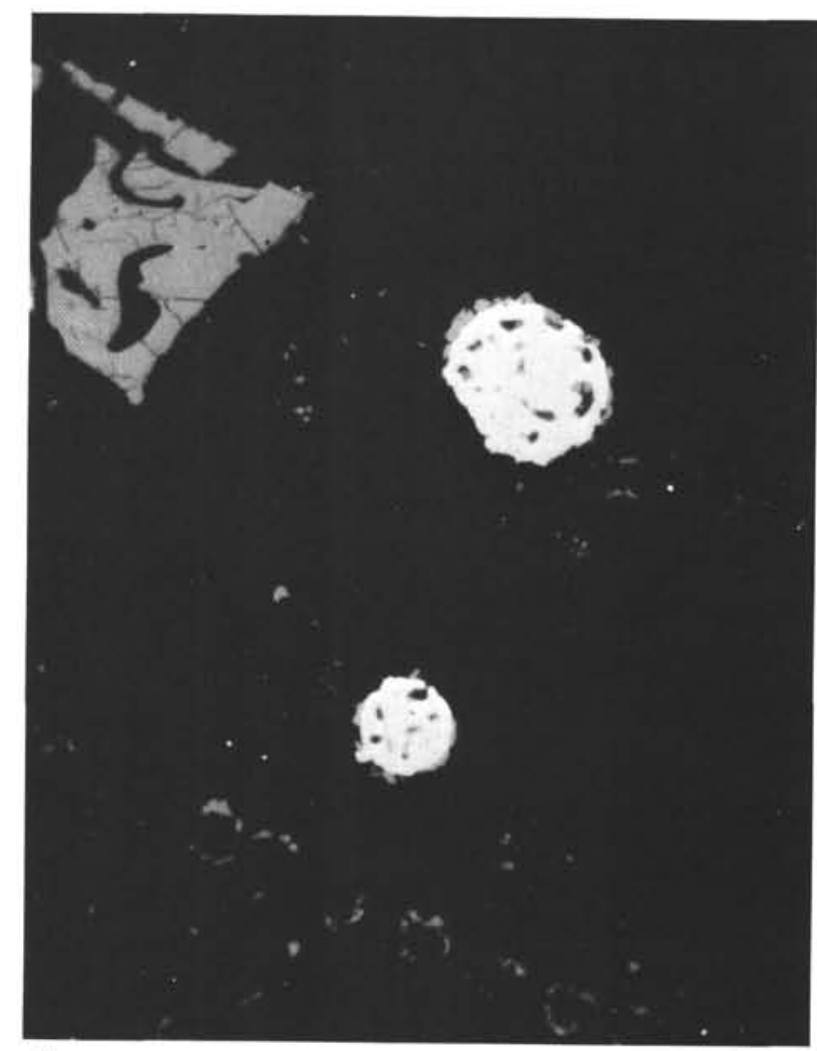

1

$50 \mu \mathrm{m}$

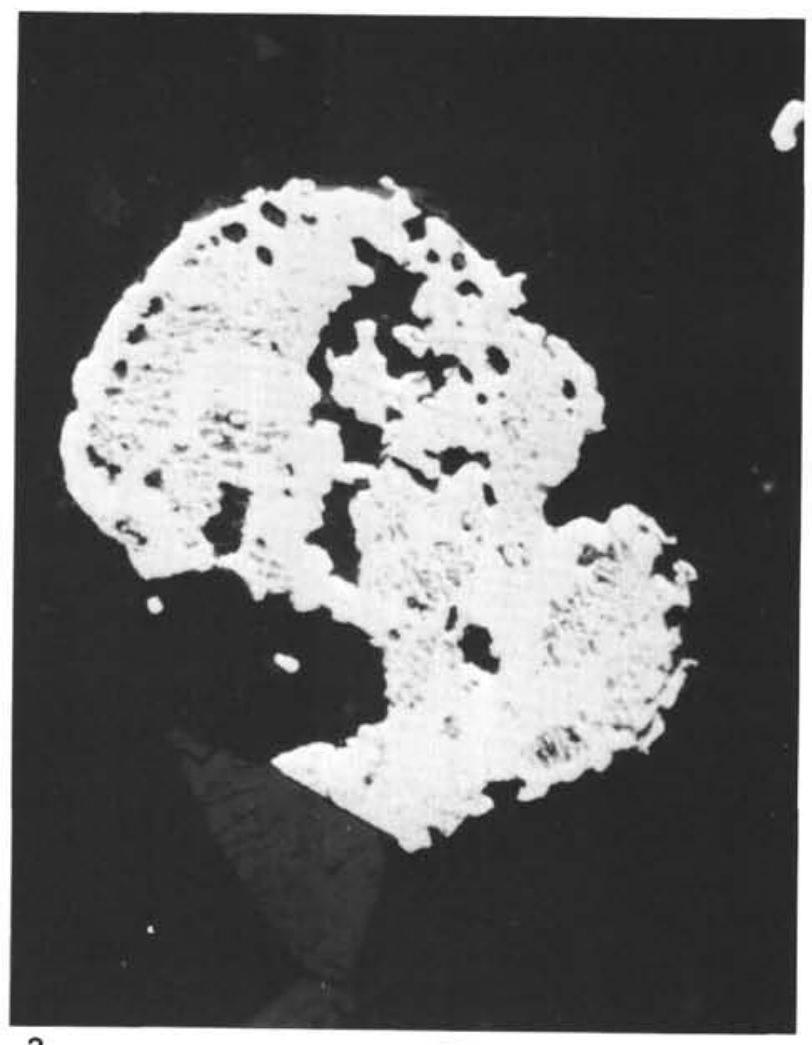

3

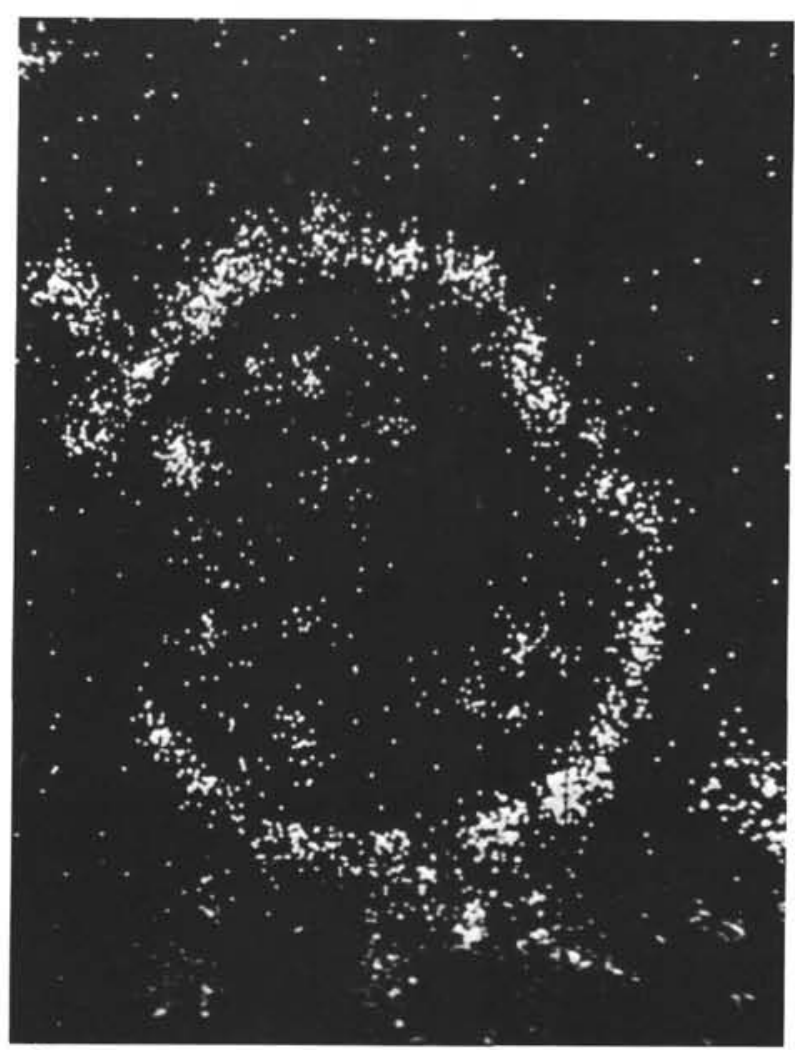

2

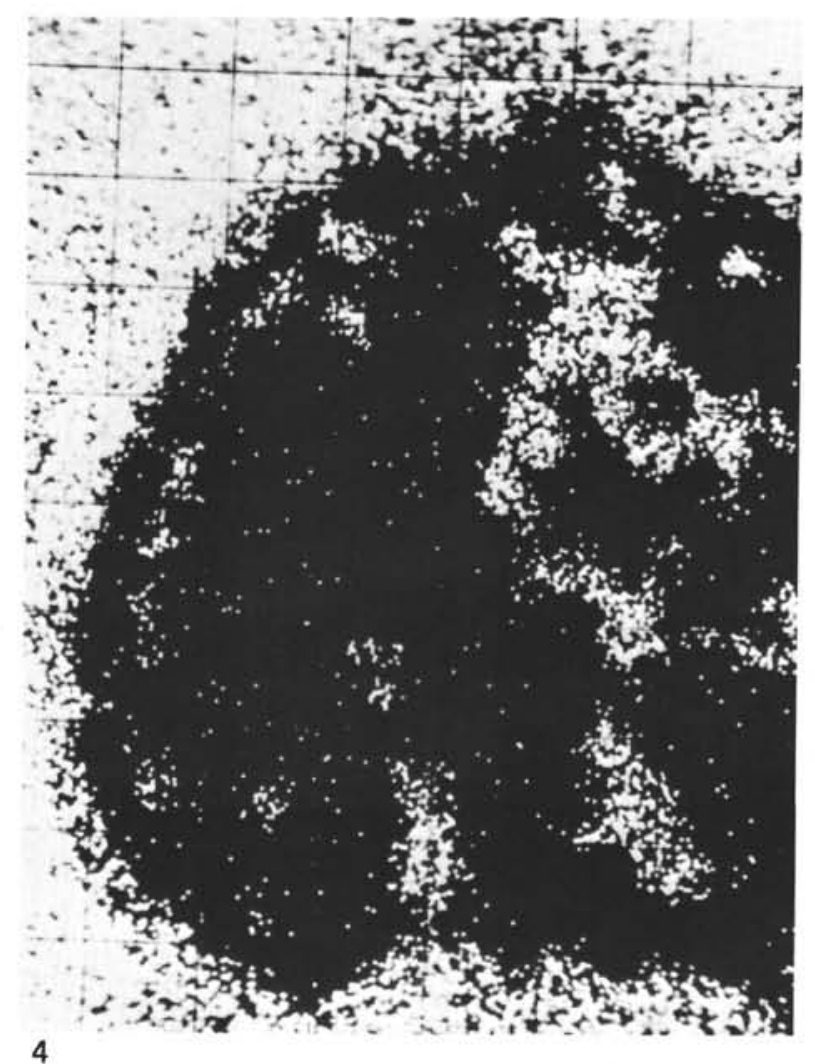


PLATE 3

Figure 1 Interstitial pyrrhotite rimmed by $\mathrm{Cu}$-rich sulfide, Sample 418A-85-4, 68-70 cm. Cracks and dark inclusions are silicates; small light gray inclusions are magnetite. Analyses 52 and 53 in Table 2. Reflected light.

Figure 2 Cu X-ray beam scanning image of a portion of the grain of Figure 1.

Figure 3 Si-X-ray beam scanning image of the same region as Figure 2 showing high $\mathrm{Si}$ contents of the $\mathrm{Cu}$-rich sulfide. The silicate and sulfide phases are intergrown on a submicron scale.

Figure 4 Sulfide globule with well developed Cu-rich sulfide rim surrounding pyrrhotite, Sample 418A-85-4, $68-70 \mathrm{~cm}$, interpreted to be intermediate in texture between primary unrecrystallized globules and interstitial grains similar to that of Figure 1. Note trellis ilmenite oxidation "exsolution" in the ulvospinel. Oil immersion. 


\section{PLATE 3}

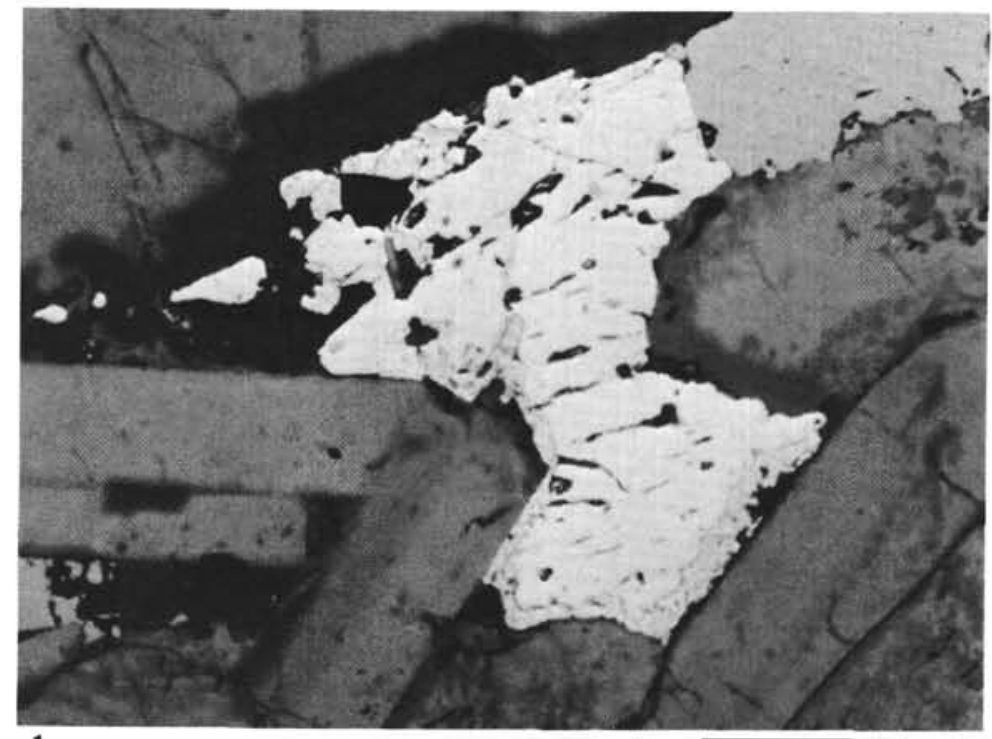

$100 \mu \mathrm{m}$
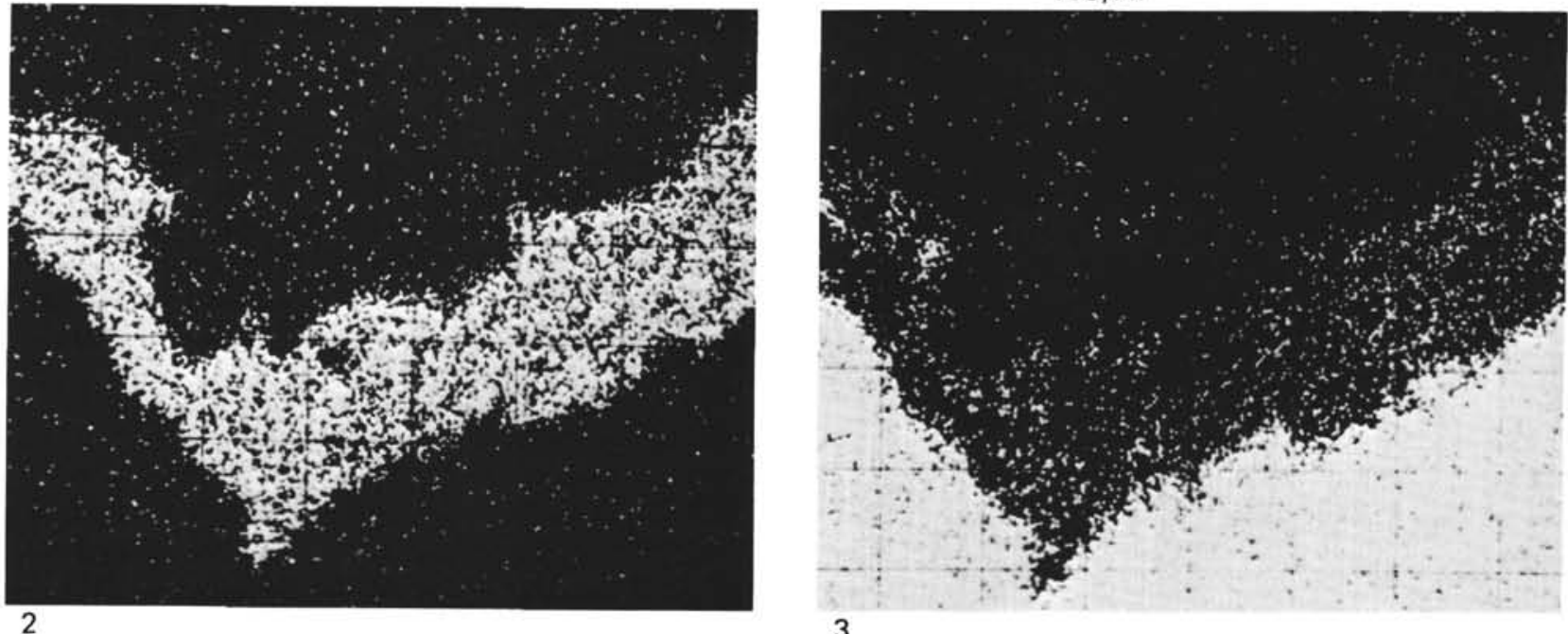

3

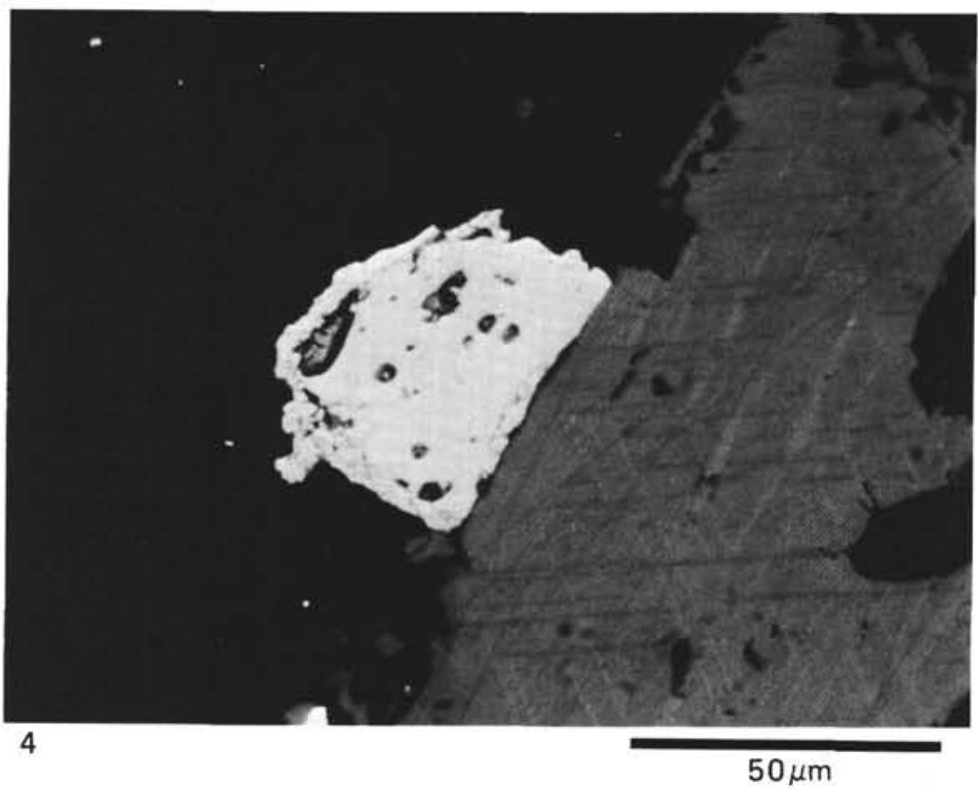


PLATE 4

Figure 1 Intergranular pyrite replacing a portion of the mesostasis, Sample 418A-77-2, 54-56 cm. Euhedral light grains are ulvospinels. Reflected light.

Figure 2 Pyrite (white)-chalcopyrite (white, slightly mottled surface) grain interpreted to have been a globule, Sample 418A-79-1, 39-41 cm. Note partial oxide rim and replacement pyrite beyond boundary of former globule. Oil immersion. 


\section{PLATE 4}
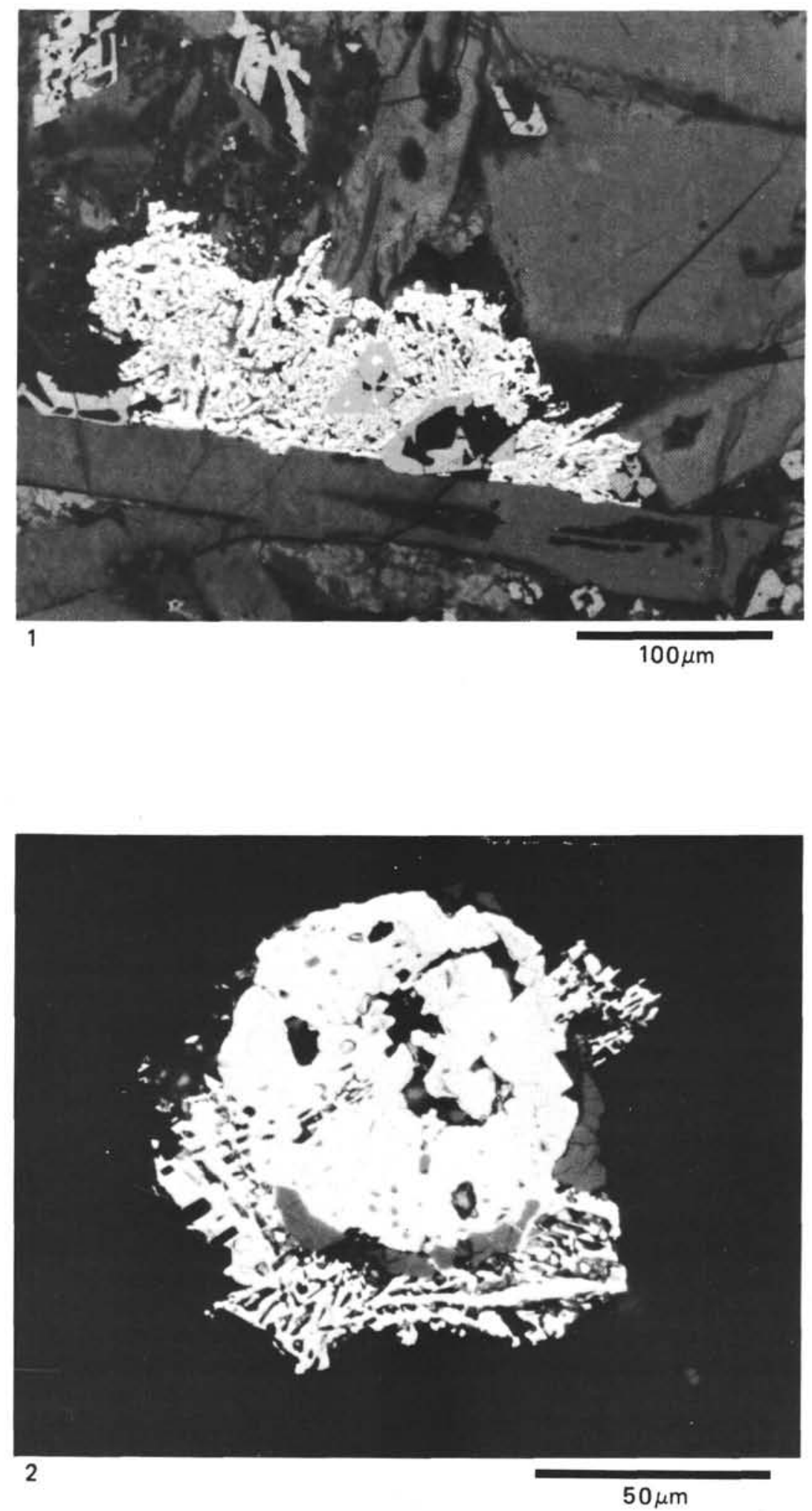